\title{
The ADAAA: Opening the Floodgates
}

\author{
AMELIA MICHELE JOINER*
}

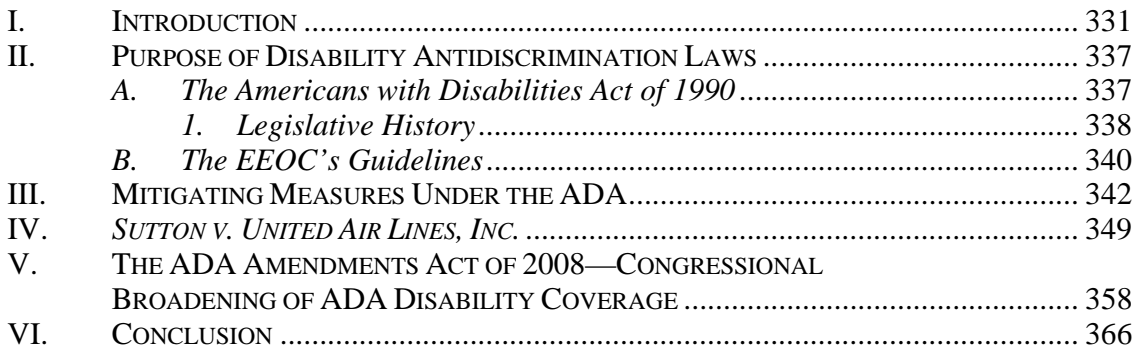

\section{INTRODUCTION}

For centuries, America has been known as the land of opportunity, where everyone has the opportunity to do anything that he dares to dream. These dreams, however, are often stifled for millions of Americans. These dreams can be stifled by economic inequality, economic immobility, and rampant discrimination-whether that discrimination has occurred on the basis of race, gender, age, religious affiliation, national origin, or

* Assistant Professor of Law, Duquesne University School of Law. The Author would like to thank Professor Charles Sullivan, Seton Hall Law School, for his invaluable insight during the editing of this Article, the Honorable Joy Flowers Conti of the United States District Court for the Western District of Pennsylvania, and Professors Martha Jordan and Kellen McClendon for their input and insightful comments. The Author would also like to thank Jonathan Bechtel for research and editing support. Finally, the Author thanks Ashley Cagle for her insightful thought, diligence, hard work, and unwavering support. 
even disability. Indeed, individuals with disabilities tend to be isolated and segregated from the rest of society. ${ }^{1}$

On July 26, 1990, to prevent discrimination related to persons with disabilities, Congress passed the Americans with Disabilities Act (ADA). ${ }^{2}$ The ADA was enacted to prohibit any employment practice or decision that adversely affects the opportunities or status of a "qualified individual." 3 Congress sought to "assure equality of opportunity, full participation, independent living, and economic self-sufficiency" for disabled individuals. ${ }^{4}$ The original purpose of the ADA was "(1) to provide a clear and comprehensive national mandate for the elimination of discrimination against individuals with disabilities; [and] (2) to provide clear, strong, consistent, enforceable standards addressing discrimination against individuals with disabilities. $" 5$ There is a three-pronged definition for disability in the ADA, which is taken in large part from the Rehabilitation Act of 1974 (Rehabilitation Act): “ "(A) a physical or mental impairment that substantially limits one or more of the major life activities of such individual; (B) a record of such an impairment; or (C) being regarded as having such an impairment."7 The ADA provides

1. 42 U.S.C. $\S 12101(\mathrm{a})(2)$ (2006).

2. Id. § 12101; see also Michael C. Falk, Lost in the Language: The Conflict Between the Congressional Purpose and Statutory Language of Federal Employment Discrimination Legislation, 35 RUTGERs L.J. 1179, 1206 (2004). Although the ADA Amendments Act of 2008 became effective on January 1, 2009, the ADA is still effective with respect to the litigation that commenced before the effective date of the ADA Amendments Act of 2008. See Rivers v. Roadway Express, Inc., 511 U.S. 298, 313 (1994) (holding that changes to statute do not apply retroactively unless Congress expressly intends to reach conduct preceding the "corrective" amendment); see also Jenkins v. Nat'l Bd. of Med. Exam'rs, No. 08-5371, 2009 WL 331638, at *2 (6th Cir. Feb. 11, 2009); EEOC v. Argo Distrib., LLC, 555 F.3d 462, 469-70 n.8 (5th Cir. 2009); Kiesewetter v. Caterpillar Inc., No. 08-2140, 2008 WL 4523595, at *1 (7th Cir. Oct. 9, 2008).

3. A qualified individual is defined as "an individual with a disability who, with or without reasonable accommodation, can perform the essential functions of the employment position that such individual holds or desires.” 42 U.S.C. § 12111(8) (2006).

4. Id. § 12101(a)(8). Congress's enactment of the ADA was not for just altruistic purposes. Congressional findings indicated that the United States was spending billions of dollars in "unnecessary expenses resulting from dependency and nonproductivity" related to individuals with disabilities. Id. § 12101(a)(9).

5. Id. $\S 12101(\mathrm{~b})(1)-(2)$. Other purposes of the ADA include ensuring that the "Federal Government plays a central role in enforcing the standards" and invoking "the sweep of congressional authority . . . to address the major areas of discrimination faced day-to-day by people with disabilities." Id.

6. 29 U.S.C. \& 794 (2006). The three-pronged disability definition of the Rehabilitation Act is virtually identical to the three-pronged disability definition of the ADA.

7. 42 U.S.C. § 12102(2) (2006); see also Bragdon v. Abbott, 524 U.S. 624, 630 (1998) (outlining the three-part query to ascertain whether an individual has met the specific requirements of the ADA's disability definition); Chiesa v. N.Y. State Dep’t of 
that the Equal Employment Opportunity Commission (EEOC) is responsible for adopting regulations to implement the ADA.

In 1991, the EEOC issued guidelines and an interpretive appendix. ${ }^{8}$ The EEOC's definition of "major life activities" includes, but is not limited to, "caring for oneself, performing manual tasks, walking, seeing, hearing, speaking, breathing, learning, and working." " "Substantially limits" is defined as:

(i) Unable to perform a major life activity that the average person in the general population can perform; or (ii) [s]ignificantly restricted as to the condition, manner, or duration under which an individual can perform a particular major life activity as compared to the condition, manner, or duration under which the average person in the general population can perform that same major life activity. ${ }^{10}$

Although the ADA and the EEOC's interpretive guidelines and appendix provide a comprehensive statutory and regulatory framework to determine whether an individual is disabled, the ADA was notably silent in addressing whether "that determination is to be made with or without regard to mitigating measures such as medications."11 As a result, courts considering claims brought pursuant to the ADA, under prong one, were faced with the arduous task of interpreting not only inconsistent portions of the ADA's legislative history ${ }^{12}$ but also conflicting cases from lower courts

Labor, 638 F. Supp. 2d 316, 322 (N.D.N.Y. 2009). The EEOC defines a physical or mental impairment as "[a]ny physiological disorder . . . affecting one or more of the following body systems: neurological, musculoskeletal, special sense organs, respiratory (including speech organs), cardiovascular, reproductive, digestive, genitor-urinary . . . organic brain syndrome, emotional or mental illness, and specific learning disabilities.” 29 C.F.R. $\S 1630.2(\mathrm{~h})(1)-(2)(2008)$.

8. See 42 U.S.C. § 12116 (2006) (requiring the EEOC to issue regulations within one year of the ADA's enactment).

9. Chiesa, 638 F. Supp. 2d at 322 n.2 (citing 29 C.F.R. § 1630.2(i) (2008)).

10. 29 C.F.R. $\S 1630.2(\mathrm{j})(1)(2008)$. In determining whether a person is substantially limited, factors to be considered include "(i) [t]he nature and severity of the impairment; (ii) [t]he duration or expected duration of the impairment; and (iii) [t]he permanent or long term impact, or the expected permanent or long term impact of or resulting from the impairment.” Id. § 1630.2(j)(2).

11. Timothy Stewart Bland, The Determination of Disability Under the ADA: Should Mitigating Factors Such As Medications Be Considered?, 35 IDAHO L. REV. 265, 269-70 (1999).

12. The House Labor Report suggests that disability should be determined without regard to mitigating measures. See H.R. REP. No. 101-485, pt. 3, at 28-29 (1990), as reprinted in 1990 U.S.C.C.A.N. 303, 334. At least one Senate report, however, indicates that the focus should be on an impairment's effects on the individual with the impairment, not on the impairment's qualities. See S. REP. No. 101-116, at 22-23 (1989). 
decided under the Rehabilitation Act. $^{13}$ Needless to say, courts were often in disagreement about how best to determine whether an individual had a disability as that term is defined by the ADA.

Struggling to make such a determination, in 1998, the United States Court of Appeals for the Fifth Circuit interpreted how to address the issue of mitigating measures. In Washington v. HCA Health Services of Texas, Inc., the court held that whether an individual must be evaluated with or without regard to mitigating measures depends both on the nature of the impairment and the mitigating measures employed by the individual. ${ }^{14}$ Thus, the court in Washington found that these issues must be considered on a case-by-case basis to determine whether the individual's impairment and the accompanying mitigation fall within the scope of the EEOC guidelines and the ADA's legislative history. ${ }^{15}$ Nearly a decade after the ADA's enactment, however, the United States Supreme Court limited the breadth of the ADA by narrowing its scope. The Supreme Court, in Sutton v. United Air Lines, Inc., held that a court's determination of disability should be made with reference to mitigating measures, such as eyeglasses and contact lenses. ${ }^{16}$

Nine years later, Congress responded to the Supreme Court's interpretation of disability under the ADA by enacting the ADA Amendments Act of 2008 (ADAAA) ${ }^{17}$ The ADAAA renounces previous Supreme Court decisions that held, among other things, that the term "disability" should not be construed narrowly and instead mandates broader coverage. Specifically, the ADAAA requires that " $[\mathrm{t}] \mathrm{he}$ determination of whether an impairment substantially limits a major life activity shall be made without regard to the ameliorative effects of mitigating measures."18 In enacting the ADAAA, Congress, while trying to fulfill the lofty and noble goal of equal treatment for disabled individuals, drafted legislation to respond to the widespread disagreement among this country's courts. Nevertheless, in relying on the all-ornothing approach when considering mitigating measures, the ADAAA

13. See infra note 61

14. 152 F.3d 464, 471 (5th Cir. 1998), vacated, 527 U.S. 1032 (1999).

15. Id.

16. 527 U.S. 471, 475 (1999), superseded by statute, ADA Amendments Act of 2008, 42 U.S.C. § 12101(a)-(b) (Supp. 2009).

17. 42 U.S.C. $\S 12102$ (Supp. 2009). The ADAAA utilizes the same three-pronged disability definition as its predecessors, the ADA and the Rehabilitation Act. To review, the definition is (a) a physical or mental impairment that substantially limits one or more major life activities of such individuals; (b) a record of such an impairment; or (c) being regarded as having such an impairment. See id. § 12102(2) (2006).

18. Id. § 12102(4)(E)(i) (Supp. 2009). 
still did not adequately address the issue of equality for disabled individuals in the workplace. Accordingly, it is the middle-of-the-road approach enumerated by the Washington court that would best suit the needs of disability rights by further promoting a case-by-case analysis and rejecting a per se finding of disability in any instance. ${ }^{19}$

This Article will examine whether Congress erred in enacting the ADAAA to include the provision that mitigating measures will not be taken into account when determining whether an individual is disabled under prong one of the ADA's disability definition. ${ }^{20}$ With the incorporation of this language, Congress took away the individualized assessment necessary for ADA interpretation and replaced it with a per se disabled format for particular conditions, such as diabetes and epilepsy. ${ }^{21}$ Simply stated, the ADAAA approach to the mitigating measures analysis, which negated the individualized disability assessment that Congress envisioned, does not promote the best possible determination of whether an individual should be covered under prong one of the ADAAA.

Part II of this Article will explore the purpose of the ADA, which is to protect individuals who are truly disabled from discrimination in the workplace. Part III will discuss the court decisions that rely upon and reject consideration of mitigating measures in an effort to determine whether an individual was disabled under prong one of the ADA. Part IV will discuss the judicial narrowing of the ADA with an in-depth discussion of the Supreme Court's decision in Sutton v. United States

19. The court in Washington declined to consider mitigation measures in every case. Instead, the court reasoned that an analysis of an individual's ameliorative efforts must be conducted in order to determine whether mitigating measures should be considered. The Washington court's approach is more of a middle-of-the-road approach, whereas the Supreme Court's finding in Sutton that mitigating measures must always be considered and Congress's direction in the ADAAA that mitigating measures should not be considered both employ all-or-nothing approaches.

20. "Prong one" is a physical or mental impairment that substantially limits one or more major life activities of such individual. 42 U.S.C. $§ 12102(2)(A)$. "Prong two" is a record of such impairment. Id. $\S 12102(2)(\mathrm{B})$. "Prong three" is being regarded as having such an impairment. Id. $\S 12102(2)(C)$. This Article focuses only on prong one of the ADA disability definition with a mindful eye to future articles, which will explore the remaining facets of the definition.

21. Congress denies that the ADAAA will have the effect of creating a class of per se disabled individuals, yet the net result is exactly that, particularly in the case of diabetics. Once an individual utilizes insulin to control her diabetes, under the ADAAA that individual is automatically considered disabled without regard to the individual's current condition. 
Air Lines, Inc. The Court's treatment of mitigating measures will be explored, particularly Sutton's groundbreaking holding that for purposes of the ADA an individual's disability status should be made with regard to mitigating measures that are utilized to control that person's otherwise disabling impairment.

Finally, in Part V, the Article will discuss the changes mandated by the ADAAA and address whether Congress has erred in enacting those changes. This Part will examine the Washington court's disability analysis of first categorizing mitigating measures according to seriousness and type, and then making the determination of whether a finding of disability under prong one is appropriate. This is the proper approach to disability analysis because it promotes the individualized inquiry that is necessary for a proper prong one interpretation of the ADAAA's disability definition. The foundational query will be whether the ADAAA's broader definition of the term disabled will inevitably generate a flood of litigation by individuals who should not be protected under prong one of the ADAAA.

This Article is not meant to address every change mandated by Congress with the passage of the ADAAA. Nor is this article meant to determine who should and should not be considered disabled under prong one of the ADAAA. ${ }^{22}$ Rather the Article is meant to explore the narrow issue of the effect of congressional action in rejecting consideration of mitigating measures when determining an individual's disability status under prong one of the ADAAA.

22. In determining who is disabled under the meaning of the ADA it must first be determined who falls into the category of being disabled. There are number of approaches to defining the term disability under the ADA. One approach, most common in the lower federal courts, is to apply the ADA's coverage only to those with severe biological impairments. Robert L. Burgdorf Jr., "Substantially Limited” Protection from Disability Discrimination: The Special Treatment Model and Misconstructions of the Definition of Disability, 42 VILL. L. REV. 409, 469-488 (1997). This is known as the "truly disabled" approach. See also Arlene Mayerson, Restoring Regard for the "Regarded As" Prong: Giving Effect to Congressional Intent, 42 VILL. L. REV. 587, 591-98 (1997). A second approach advocated by disability rights activists is the "no-protected-class approach." Samuel Bagenstos, Subordination, Stigma, and "Disability," 86 VA. L. REV. 397, 47384 (2000). This approach views disability as a product of social attitudes and choices towards and individual rather than looking at the individual's biological characteristics. Taking this approach treats the statute as mandating a universal regime of individualized accommodation and eliminates the need to create a separate category for people with disabilities. It has also been suggested that a subordination-based approach be taken in determining the meaning of disability under the ADA. This approach defines disability from a societal viewpoint. Those who society places in a subordinated class and treats differently than those considered normal would qualify as disabled. These approaches attempt to define disability under the ADA as a whole. 


\section{PURPOSE OF DISABILITY ANTIDISCRIMINATION LAWS}

\section{A. The Americans with Disabilities Act of 1990}

Due to the inadequacies of the Rehabilitation Act in the years prior to the passage of the ADA, an intense movement began to protect the disabled from discrimination. ${ }^{23}$ During this time, President Ronald Reagan appointed Vice President George H.W. Bush as head of the Regulatory Relief Task Force ${ }^{24}$ which was charged with drafting more inclusive legislation for the handicapped. ${ }^{25}$ Vice President Bush sought advice from the National Council of the Handicapped (Council), ${ }^{26}$ which in 1983, delivered the National Policy for Persons with Disabilities. ${ }^{27}$ In 1986, the Council recommended that Congress enact a law "requiring equal opportunity for people with disabilities."28

23. Although the Rehabilitation Act's intentions were to protect the disabled from discrimination, it "failed to protect most persons with disabilities because it provided only that they not be subject to discrimination 'under any program or activity receiving federal assistance."” Barbara Hoffman, Reports of Its Death Were Greatly Exaggerated: The EEOC Regulations That Define "Disability" Under the ADA After Sutton v. United Air Lines, 9 TEMP. PoL. \& CIV. RTS. L. REV. 253, 255-56 (2000). To illustrate, four months before the signing of the ADA, more than 100 protestors in wheelchairs, associated with the advocacy group Americans Disabled for Accessible Public Transit, were arrested in Washington, D.C., for staging a demonstration at the Capitol urging new disability legislation. Falk, supra note 2, at 1206.

24. Melanie D. Winegar, Big Talk, Broken Promises: How Title I of the Americans with Disabilities Act Failed Disabled Workers, 34 Hofstra L. REV. 1267, 1269 (2006). The task force was charged with paring down government programs and dismantling "administrative monstrosities," such as the affirmative action provision of the Rehabilitation Act. Id.

25. Id. President Reagan believed that "any new law would have to focus on employment, but not affirmative action, and on opportunities, but not entitlements." Id. at 1270 .

26. Id. See Falk, supra note 2, at 1207 (noting that the National Council on the Handicapped was established as an independent federal agency); Chai Feldblum, Medical Examinations and Inquiries Under the Americans with Disabilities Act: A View from the Inside, 64 TEMP. L. REV. 521, 523 n.15 (1991) (discussing the disability rights advocacy groups that worked together to draft the ADA). The National Council on the Handicapped, now called the National Council on Disability, is a twelve-member council appointed by the President and charged with reviewing federal laws and programs affecting persons with disabilities and making recommendations to the President and to Congress for improving such programs and laws. Id. at 523-24 n.16.

27. Winegar, supra note 24 , at 1270 . The goals of the policy were to help people with disabilities achieve " "maximum life potential, self-reliance, independence, productivity, and equitable mainstream social participation in the most productive and least restrictive environment."' Id. (citation omitted). Vice President Bush relied upon the fifteen-member council to formulate the recommendations to Congress. Id.

28. Id. 


\section{Legislative History}

In October 1987, a small number of individuals met to review a draft of the first "Americans with Disabilities Act," authored by Robert L. Burgdorf Jr. ${ }^{29}$ The early bill's structure was taken from section 504 of the Rehabilitation Act's regulations promulgated by the U.S. Department of Health, Education, and Welfare. ${ }^{30}$ The decision to model the ADA on previous legislation was intentional ${ }^{31}$ because Burgdorf and others:

[D]id not wish to start the battle for a comprehensive antidiscrimination law at "ground zero"- that is, they rejected the idea of drafting a general law that would ... be dependent on the issuance of new regulations for its substantive content. Rather, the decision was made to incorporate the best of what had been developed through regulations and case law under section 504 into the ADA itself. ${ }^{32}$

On July 26, 1990, President George H.W. Bush, in signing the ADA into law, "hailed the bipartisan efforts in Congress, the tireless work of numerous disability rights organizations, and the 43 million Americans with disabilities who led the charge." 33 It was President Bush's stated intention to ensure that "every man, woman, and child with a disability [could] . . . pass through once closed doors into a bright new era of equality, independence, and freedom."34

With the passage of the ADA, Congress listed in the preamble its findings and purposes with regard to discrimination against the disabled. ${ }^{35}$

29. Feldblum, supra note 26, at 523. Burgdorf was a staff person for the National Council on the Handicapped. The Council had held hearings over the previous years and developed two reports regarding discrimination against individuals with disabilities. Id. at 523-24. The second report also called for new antidiscrimination legislation for people with disabilities. Id. at 524 .

30. Id. The U.S. Department of Health, Education, and Welfare is now titled the U.S. Department of Health and Human Services. U.S. Department of Health \& Human Services, http://www.dhhs.gov/about/hhshist.html (last visited Apr. 19, 2010).

31. Feldlum, supra note 26, at 524. The ADA was derived from the Rehabilitation Act of 1973 and Title VII of the Civil Rights Act of 1964. Id. at 521. The substantive provisions were culled from the Rehabilitation Act, although the procedural requirements were modeled from the Civil Rights Act of 1964. Id. at 522.

32. Id. at 524. Decisions such as who is a person with a disability, what constitutes discrimination on the basis of disability, or what is required as a reasonable accommodation are all derived from similar substantive requirements established under the Rehabilitation Act. Id. at $522-24$

33. Id. at 531; Winegar, supra note 24, at 1271.

34. Wendy E. Parmet, Plain Meaning and Mitigating Measures: Judicial Interpretations of the Meaning of Disability, 21 BERKELEY J. EMP. \& LAB. L. 53, 53 (2000) (quoting Signing of the Americans with Disabilities Act by President George Bush, FED. NEWS SERV., July 26, 1990).

35. The purposes set out in the Act are, in pertinent part:

1. [T]o provide a clear and comprehensive national mandate for the elimination of discrimination against individuals with disabilities; 
Title I ${ }^{36}$ prohibits employment discrimination "against a qualified individual with a disability because of the disability of such individual in regard to job application procedures, the hiring, advancement, or discharge of employees, employee compensation, job training, and other terms, conditions, and privileges of employment." ${ }^{37}$ The ADA defines disability as "(A) a physical or mental impairment that substantially limits one or more of the major life activities of such individual; (B) a record of such an impairment; or (C) being regarded as having such an impairment."38

The ADA's definition of a disability, based on the Rehabilitation Act, has been the topic of much criticism. ${ }^{39}$ The definition is "notoriously vague" and is thus left vulnerable to varying interpretations. ${ }^{40}$ Although Congress may have intended this to bring about individualized inquiries, the problem with leaving this "interpretive wiggle room"41 is that the judiciary, not the legislature, determines whether a disability claim succeeds or fails. $^{42}$

2. to provide clear, strong, consistent, enforceable standards addressing discrimination against individuals with disabilities; [and]

3. to ensure that the Federal Government plays a central role in enforcing the standards established ... on behalf of individuals with disabilities . . . .

42 U.S.C. § 12101(b)(1)-(3) (2006); see also Falk, supra note 2, at 1209.

36. 42 U.S.C. $\S 12111$ (2006). Title I applies to private employers with fifteen or more employees. Id. § 12111(5)(A).

37. Id. § 12112(a) (2006). A qualified individual is one who, with or without reasonable accommodation, can perform the essential functions of the employment position that such individual holds or desires. See id. § 12111(8).

38. Id. § 12102(2) (2006). The ADA's disability definition was taken in large part from the Rehabilitation Act's three-pronged handicapped definition. See 29 U.S.C. § 794 (2006)

39. See Falk, supra note 2, at 1207 (noting that the Rehabilitation Act was "narrow in scope with respect to its applicability in the private sector”); Hoffman, supra note 23, at 256 (writing that Americans with disabilities "had little recourse against employment discrimination"). The Author realizes that it is not abnormal that statutes are often criticized for a variety of reasons. The Author, however, points out that it is abnormal that the criticism that occurred in the case of the disability definition originated from open dialogues among the legal community and scholars to judicial anarchy in the application and implementation of the ADA in the courts

40. Falk, supra note 2, at 1211.

41. Id.

42. Id. 


\section{B. The EEOC's Guidelines}

The EEOC is authorized under the ADA to issue regulations to carry out the purpose of Title I. ${ }^{43}$ On July 26, 1991, the EEOC issued its ADA regulations. ${ }^{44}$ The language from the ADA's disability definition, "physical or mental impairment that substantially limits one or more of the major life activities of such individual," is incorporated into the EEOC's guidelines. $^{45}$

The EEOC regulations, however, provide more specificity than the statutory language by defining key terms of the ADA disability definition, such as "physical or mental impairment," 46 "major life activities," 47 and "substantially limits." 48 The EEOC regulations also "emphasize[] the

43. 42 U.S.C. § 12116 (2006); see also Hoffman, supra note 23, at 258.

44. 29 C.F.R. § 1630.1 (2008). The EEOC issued both regulations and an appendix entitled Interpretive Guidance that "addresses the major provisions of [Title I] and explains the major concepts of disability rights.” Hoffman, supra note 23, at 262 n.57.

45. 29 C.F.R. § 1630.2(g)(1) (2008). In conjunction with the EEOC's regulations, the Department of Justice (DOJ) also issued its own interpretive guidelines that were parallel to the Rehabilitation Act's section 504 regulations. See Architectural and Transportation Barriers Compliance Board, 56 Fed. Reg. 35,408 (July 26, 1991) (codified at 28 C.F.R. $\S 36.101$ (2008)). Specifically, the DOJ noted that disability determinations should not take into account mitigating measures. See 28 C.F.R. pt. 36, app. B, at 620 (1999).

46. 29 C.F.R. $\$ 1630.2(\mathrm{~h})(1)-(2)$ (2008). Physical or mental impairment means:

1. Any physiological disorder, or condition, cosmetic disfigurement, or anatomical loss affecting one or more of the following body systems: neurological, musculoskeletal, special sense organs, respiratory (including speech organs), cardiovascular, reproductive, digestive, genito-urinary, hemic and lymphatic, skin, and endocrine; or

2. Any mental or psychological disorder, such as mental retardation, organic Id. brain syndrome, emotional or mental illness, and specific learning disabilities.

47. Major life activities means "functions such as caring for oneself, performing manual tasks, walking, seeing, hearing, speaking, breathing, learning, and working.” Id. $\S 1630.2(\mathrm{i})$.

48. A substantial limitation is defined as:

1. The term substantially limits means:

i. Unable to perform a major life activity that the average person in the general population can perform; or

ii. Significantly restricted as to the condition, manner or duration under which an individual can perform a particular major life activity as compared to the condition, manner, or duration under which the average person in the general population can perform that same major life activity.

2. The following factors should be considered in determining whether an individual is substantially limited in a major life activity:

i. The nature and severity of the impairment;

ii. The duration or expected duration of the impairment; and

iii. The permanent or long term impact, or the expected permanent or long term impact of or resulting from the impairment.

3. With respect to the major life activity of working- 
idea that careful individual assessment ha[s] to be made in every case" to determine whether a person had a disability within the meaning of the ADA. ${ }^{49}$ Additionally, the Interpretive Guidance ${ }^{50}$ expounds upon "substantially limits" by stating that "[t]he existence of an impairment is to be determined without regard to mitigating measures such as medicines or assistive or prosthetic devices."51 The EEOC purposefully included this provision to "ensure that the ADA protects individuals who rely upon assistive devices or medications to perform a major life activity."52 Despite the regulatory provision that required disability analysis to be made without regard to mitigating measures, some courts made disability determinations by taking into consideration the effects of medications or other assistive devices. ${ }^{53}$

i. The term substantially limits means significantly restricted in the ability to perform either a class of jobs or a broad range of jobs in various classes as compared to the average person having comparable training, skills and abilities. The inability to perform a single, particular job does not constitute a substantial limitation in the major activity of working.

ii. In addition to the factors listed in paragraph $(\mathrm{j})(2)$ of this section, the following factors may be considered in determining whether an individual is substantially limited in the major life activity of "working":

A. The geographical area to which the individual has reasonable access;

B. The job from which the individual has been disqualified because of an impairment, and the number and types of jobs utilizing similar training, knowledge, skills or abilities, within that geographical area, from which the individual is also disqualified because of the impairment (class of jobs); and/or

C. The job from which the individual has been disqualified because of an impairment, and the number and types of other jobs not utilizing similar training, knowledge, skills or abilities, within that geographical area, from which the individual is also disqualified Id. $\S 1630.2(\mathrm{j})(1)-(3)$. because of the impairment (broad range of jobs in various classes).

49. Chai R. Feldblum et al., The ADA Amendments Act of 2008, 13 TEX. J. C.L. \& C.R. 187, 192 (2008) (citing Chai R. Feldblum, Definition of Disability Under Federal Anti-Discrimination Law: What Happened? Why? And What Can We Do About It?, 21 BERKELEY J. EMP. \& LAB. L. 91, 136 (2000)).

50. See supra note 44.

51. Hoffman, supra note 23, at 264; see also 28 C.F.R. pt. 36, app. B, § 36.104 (1999) (“[P]ersons with impairments, such as epilepsy or diabetes, that substantially limit a major life activity, are covered under the first prong of the definition of disability, even if the effects of the impairment are controlled by medication.”).

52. Hoffman, supra note 23, at 264.

53. See infra Part III. 


\section{Mitigating MEASURES UnDER THE ADA}

The ADA protects only those who fall within its statutory threepronged disability definition: (a) physical or mental impairment that substantially limits one or more of the major life activities of such individual; (b) a record of such an impairment; or (c) being regarded as having such an impairment. ${ }^{54}$ By the early 1990s, case law interpreting the definition and its accompanying regulations had generally afforded a broad reading of the definition. ${ }^{55}$ Soon, however, a line of demarcation emerged among courts when faced with plaintiffs who claimed that they suffered from an impairment substantially limiting a major life activity. ${ }^{56}$ On one side, disability is construed narrowly, applying "only to those individuals who by virtue of their condition are incapable of living an independent, economically productive life."57 Consistent with this narrow approach, an individual whose impairment is controlled by "medication, surgery, or an assistive device" is no longer disabled. ${ }^{58}$

On the other hand, the term disability can also be construed more broadly. As one commentator put it, "[A]pplying the term to individuals who encounter unnecessary hindrances in their quest for self-sufficiency due to the interaction of their biological selves and the social world around them, the existence of mitigating measures should not preclude a finding of disability."59 Simply put, the usage of mitigating measures does not mean that the person is no longer disabled. ${ }^{60}$

54. 42 U.S.C. § 12102(2) (2006).

55. See Sch. Bd. of Nassau County v. Arline, 480 U.S. 273, 284-86 (1987) (providing a broad interpretation of disability); 29 C.F.R. $§ 1630.1$ (2009). The statute's drafters were "content to provide a general definition of disability, comfortable with the thought that it would help promote the self-sufficiency of some unspecified group of over 40 million Americans." Parmet, supra note 34, at 61.

56. Michael J. Puma, Respecting the Plain Language of the ADA: A Textualist Argument Rejecting the EEOC's Analysis of Controlled Disabilities, 67 GEO. WASH. L. REV. 123, 127-29 (1998). To establish a claim of impairment substantially limiting a major life activity, a court must determine whether (1) an individual's condition is a physical impairment; (2) a claimed activity that the impairment affects is a major life activity; and (3) the impairment substantially limits that major life activity. Id. at 125.

57. Parmet, supra note 34, at 62.

58. Id. Due to the implementation of the mitigating measure, the individual is said to have "'overcome' his or her physical incapacity and is now able to be self-sufficient." Id.

59. Id. (footnotes omitted)

60. The Author would like to point out that even if the use of mitigating measures precludes a plaintiff from pursuing a claim under prong one, those measures can nevertheless be successfully litigated under the second prong-record of an impairment-or the third prong-being regarded as having such an impairment. 
Courts interpreting the ADA have been as consistently inconsistent as those addressing the Rehabilitation Act in the determination of whether, in light of mitigating measures, an individual is disabled. ${ }^{61}$ Notably, in Washington v. HCA Health Services of Texas, Inc., the United States Court of Appeals for the Fifth Circuit addressed for the first time whether a court should consider mitigating measures when determining if an individual is disabled within the meaning of the ADA. ${ }^{62}$ There, the plaintiff was employed as a senior accountant at HCA and worked a rigorous work schedule of sixty to eighty hours per week. ${ }^{63}$ Prior to his commencement of work with the employer, the plaintiff was diagnosed with Adult Still's Disease and also suffered from a related serious

61. A number of Rehabilitation Act decisions did not consider mitigating measures. See Cook v. R.I. Dep’t of Mental Health, Retardation \& Hosps., 10 F.3d 17, 23-24 (1st Cir. 1993) (holding that the mere existence of a mutable condition-a condition that is correctable by mitigating measures - does not automatically preclude an individual from coverage under the Rehabilitation Act); Gilbert v. Frank, 949 F.2d 637, 640-41 (2d Cir. 1991) (holding that an individual who suffered from polycystic kidney disease was disabled within the meaning of the Rehabilitation Act even though he utilized dialysis, which provided a mechanical substitute for the functioning of healthy kidneys); Reynolds v. Brock, 815 F.2d 571, 574 (9th Cir. 1987) (holding that even though medication controlled the plaintiff's seizures, she was still considered a handicapped individual within the meaning of the Rehabilitation Act); Miles v. Gen. Servs. Admin., No. Civ. A. 94-1945, 1995 WL 766013, at *5 (E.D. Pa. Dec. 27, 1995) (holding that although controllable with medicine, the plaintiff's diabetes, carpal tunnel syndrome, and depression, which would have otherwise substantially limited his ability to perform manual tasks and work, rendered plaintiff handicapped). There were also Rehabilitation Act decisions that did consider mitigating measures. See Chandler v. City of Dallas, 2 F.3d 1385, 1390 (5th Cir. 1993) (holding that plaintiff, whose vision did not substantially limit any of his major life activities and could be corrected to 20/60 was not handicapped within the meaning of the Rehabilitation Act); Lester v. Natsios, 290 F. Supp. 2d 11, 25 (D.D.C. 2003) (citing Toyota Motor Mfg., Ky., Inc. v. Williams, 534 U.S. 184, 195 (2002), superseded by statute, ADA Amendments Act of 2008, 42 U.S.C. § 12101(a)-(b) (Supp. 2009)) (holding that the temporary impairment from which plaintiff suffered did not satisfy the legal requirements to be a qualified individual with a disability under the Rehabilitation Act); Joyce v. Suffolk County, 911 F. Supp. 92, 96 (E.D.N.Y. 1996) (citing Forrisi v. Bowen, 794 F.2d 931, 934-36 (4th Cir. 1986), which held that "[i]t would debase [the] high purpose [of protecting the handicapped from discrimination in employment] if the statutory protections available to those truly handicapped [individuals] could be claimed by anyone whose disability was minor and whose relative severity of impairment was widely shared”) (holding that impaired vision that could be corrected did not render an individual handicapped within the meaning of the Rehabilitation Act).

62. 152 F.3d 464, 466-67 (5th Cir. 1998), vacated, 527 U.S. 1032 (1999).

63. Id. at 466 . 
kidney condition. ${ }^{64}$ The plaintiff's medical conditions required him to take four prescription medicines on a daily basis. ${ }^{65}$ Without the use of his medication, the plaintiff would have been "bedridden and unable to work." 66

During the plaintiff's employment, his medical condition worsened, which caused his physician to direct the plaintiff to work no more than fifty hours per week. ${ }^{67}$ The plaintiff asked the employer to honor this accommodation. ${ }^{68}$ Thereafter, the plaintiff worked no more than fifty hours per week. ${ }^{69}$ Shortly after the plaintiff's request for an accommodation was granted, the employer went through a workforce reduction and terminated plaintiff's employment. ${ }^{70}$ The plaintiff filed suit alleging that the employer discriminated against him on the basis of his disability and thus, violated the ADA. ${ }^{71}$

The United States Court of Appeals for the Fifth Circuit reviewed the district court's denial of the employer's motion for summary judgment. The employer asserted that the plaintiff was not disabled within the meaning of the ADA because he was not substantially limited in a major life activity while he was on medication. ${ }^{72}$ The court of appeals addressed whether the plaintiff's condition should be evaluated by taking into account mitigating measures, here his medication, or assessed in the plaintiff's unmedicated state. ${ }^{73}$ In conducting its analysis, the court found that the text of the ADA was ambiguous because it did not state whether mitigating measures should be considered when determining whether an individual is disabled. ${ }^{74}$ The court looked to the legislative history and the EEOC's interpretive guidelines to assist it in its interpretation of the ADA. ${ }^{75}$ The court addressed the various congressional

64. Adult Still's Disease is a rare form of arthritis that affects mostly twenty- to thirtyfive-year-olds and is characterized by high fevers and a salmon-colored rash. International Still's Disease Foundation, http://www.stillsdisease.org/stills_info (last visited Mar. 26, 2010).

65. Washington, 152 F.3d at 466.

66. Id.

67. Id.

68. Id.

69. Id.

70. Id.

71. Id.

72. Id.

73. Id. at $466-67$.

74. Id. at $467-68$.

75. The court relied on Guilzon v. Commissioner, 985 F.2d 819 (5th Cir. 1993), which held that when the language of a statute is unambiguous, the court will not defer to legislative history or other extrinsic aids to interpret a statute. Guilzon, 985 F.2d at 823-24 n.11. 
committee reports associated with the ADA's legislative history. The court found that the House committee reports, specifically the House Education and Labor Committee Report, indicated that the determination whether an individual has a disability must be made without consideration of mitigating measures. ${ }^{76}$

By contrast, Senate committee reports were somewhat inconsistent with the language of the House Education and Labor Committee Report. The Senate Labor and Human Resources Committee Report indicated that the evaluation of whether an individual was disabled should be made without consideration of mitigating measures. ${ }^{77}$ The Senate Labor and Human Resources Committee Report further indicated that the third prong of the definition of disability was included as a part of the ADA to "ensure that persons with medical conditions that are under control, and that therefore do not currently limit major life activities, are not discriminated against on the basis of their medical conditions."78 This Senate Committee Report considered individuals with medical conditions such as controlled diabetes or epilepsy or individuals who wear hearing aids as the type of individuals who should be protected under the third prong of the disability definition. ${ }^{79}$ Ultimately, the Washington court decided to give more weight to the House Education and Labor Committee Report, which consistently called for the disability determination to be made without consideration of mitigating measures. ${ }^{80}$

76. The House Education and Labor Committee Report provides that:

Whether a person has a disability should be assessed without regard to the availability of mitigating measures, such as reasonable accommodations or auxiliary aids. For example, a person who is hard of hearing is substantially limited in the major life activity of hearing, even though the loss may be corrected through the use of a hearing aid. Likewise, persons with impairments, such as epilepsy or diabetes, which substantially limit a major life activity are covered under the first prong of the definition of disability, even if the effects of the impairment are controlled by medication.

H.R. REP. No. 101-485, pt. 2, at 52 (1990), as reprinted in 1990 U.S.C.C.A.N. 303, 334. Similarly, the House Judiciary Committee Report contained the warning that impairments "should be assessed without considering whether mitigating measures, such as auxiliary aids or reasonable accommodations, would result in a less-than-substantial limitation." Id., pt. 3, at 28, as reprinted in 1990 U.S.C.C.A.N. 445, 451.

77. Washington, 152 F.3d at 468 (citing S. REP. No. 101-116, at 23 (1989)).

78. Id. (emphasis omitted) (citing S. REP. No. 101-116, at 24).

79. S. REP. No. 101-116, at 24.

80. See Washington, 152 F.3d at 468. The court found that the ADA, as originally enacted, more closely tracked the language and rationale of the House committee reports. 
The court relied on the EEOC's interpretive guidelines, which indicated that the determination should be made without consideration of mitigating measures. $^{81}$ In relying on the EEOC's interpretive guidelines to decide whether to consider mitigating measures, the court analyzed the amount of deference that should be given to the EEOC's guidelines and found that the guidelines were entitled to more than "minimal deference."82 Although some courts had declined to accept the guidelines as instructive and found that mitigating measures should be considered when determining whether an individual is disabled, ${ }^{83}$ the court nonetheless reached a decision that was somewhat consistent with both the EEOC's guidelines and the legislative history. To elaborate, because the Washington court promulgated a middle-of-the-road approach to disability analysis by holding that mitigating measures would be considered in some circumstances and not be considered in others, the court effectively furthered an individualized assessment of disability determinations.

Despite deciding to follow the EEOC's guidelines and the legislative history, the court in Washington maintained that a broad rather than a strict reading of these sources was more appropriate. The court found that only "serious impairments" should be considered in their unmitigated

Id. Further, the court found that the House discussions about the ADA were later in time than the Senate discussions. Id.

81. "The existence of an impairment must be determined without regard to mitigating measure such as medicines, or assistive or prosthetic devices.” 29 C.F.R. pt. 1630, app. $\S 1630.2(\mathrm{~h})$ (1998). The EEOC also suggested that the "determination of whether an individual is substantially limited in a major life activity must be made . . . without regard to mitigating measures such as medicines, or assistive or prosthetic devices.” Id. at 348.

82. Id. at 339. In conducting its analysis with respect to the amount of deference that should be shown to the EEOC's interpretive guidelines, the Washington court relied on Chevron U.S.A., Inc. v. Natural Resource Defense Council, Inc., 467 U.S. 837, 866 (1984), finding that the EEOC's guidelines were not entitled to Chevron deference but that the guidelines were entitled to some deference. Washington, 152 F.3d at 469-70. To determine the amount of deference to which the guidelines were entitled, the court considered "the circumstances of [the guidelines'] promulgation, the consistency with which the agency has adhered to the position announced, the evident consideration which has gone into its formulation, and the nature of the agency's expertise." Id. at 470 (quoting Rowinsky v. Bryan Indep. Sch. Dist., 80 F.3d 1006, 1014 n.20 (5th Cir. 1996)). The court found that the subject regulations had been part of the regulations since their inception, had been consistently interpreted, and were supported by the ADA's legislative history, and that the EEOC had significant expertise and authority to interpret the regulations. Id. The court also noted that the EEOC had the necessary expertise to promulgate the ADA regulations. Id. As such, the court found that the guidelines were entitled to more than minimal deference. Id.

83. Washington, 152 F.3d at 469 (citing Sutton v. United Air Lines, Inc., 130 F.3d 893, 902 (10th Cir. 1997), aff'd, 527 U.S. 471 (1999), superseded by statute, ADA Amendments Act of 2008, 42 U.S.C. § 12101(a)-(b) (Supp. 2009); Gilday v. Mecosta County, 124 F.3d 760, 767 (6th Cir. 1997)). 
state. ${ }^{84}$ The court reasoned that to disregard mitigating measures, as directed by the legislative history and the EEOC's interpretive guidelines:

The impairments must be serious in common parlance, and they must require that the individual use mitigating measures on a frequent basis, that is, he must put on his prosthesis every morning or take his medication with some continuing regularity. In order for us to ignore the mitigating measures, they must be continuous and recurring; if the mitigating measures amount to permanent corrections or ameliorations, then they may be taken into consideration. 85

In essence, the court held that in order to determine whether mitigating measures should be considered, a court must consider "both the nature of the impairment and the mitigating measures employed by the individual." ${ }^{\circ 6}$ Under the court's reasoning, serious conditions would be considered without regard to mitigating measures, and other impairments would be considered with regard to mitigating measures. ${ }^{87}$

Similarly, in Bartlett v. New York State Board of Law Examiners, the court considered whether an individual who suffered from a reading and learning disability but had learned to self-accommodate in a manner that enabled her to achieve average reading skills was disabled within the meaning of the ADA. ${ }^{88}$ In Bartlett, the plaintiff was a long-term sufferer from a learning disability. ${ }^{89}$ Her learning disability interfered with her ability to "identify timely and decode the written word, that is, to read as compared to the manner and conditions under which the average person in the general population can read or learn." ${ }^{90}$ In her early career, the plaintiff was employed as a teacher and focused on phonics. ${ }^{91}$ This

84. Id. at 470-71. The court reasoned that ailments such as those enumerated in the EEOC's guidelines were serious impairments. Id. Those ailments included diabetes, epilepsy, and hearing impairments. Id. The court acknowledged, however, that the determination of which ailment was serious would necessarily have to occur on a caseby-case basis. Id.

85. Id.

86. Id. at 471 .

87. Although it is clear that the Washington court's rationale would cause courts to conduct a detailed analysis with regard to whether an individual had a serious condition, such an analysis is what is required when deciding cases brought under the ADA. Courts are directed to conduct an individualized inquiry into the question of whether an individual is disabled within the meaning of the ADA. This analysis requires courts to do no more than what they necessarily must do.

88. 156 F.3d 321, 323-24 (2d Cir. 1998), vacated, 527 U.S. 1031 (1999).

89. Id. at 324 .

90. Id. at 329.

91. Id. at 326 
focus enabled her to spell and read better than most individuals with reading disabilities. $^{92}$ Despite her difficulty reading, the plaintiff was able to obtain both a Ph.D. in education and a law degree. ${ }^{93}$ Upon meeting all of the prerequisites to sit for the bar examination, the plaintiff applied to take the bar examination seeking admission to the New York State Bar. ${ }^{94}$ The plaintiff sought an accommodation from the New York State Bar in the form of additional time and certain changes with respect to recording her answers to the bar examination questions. ${ }^{95}$ The New York State Bar repeatedly denied plaintiff's requests for accommodations. ${ }^{96}$ The plaintiff failed the bar examination on four occasions. ${ }^{97}$

In finding that the plaintiff was disabled within the meaning of the ADA, the Bartlett court noted that an individual must be evaluated in an unmitigated state. ${ }^{98}$ The court found that even self-accommodations are mitigating measures that must not be considered when deciding if an individual is disabled. ${ }^{99}$ Because the court found that the plaintiff could not read or learn the way most people in society do, she was substantially limited in a major life activity and thus disabled.

Likewise, in Baert v. Euclid Beverage, Ltd., the court declined to find that certain impairments were per se disabilities under the ADA but acknowledged that the plaintiff was disabled. ${ }^{101}$ In Baert, the plaintiff was employed as a commercial driver for a beverage company. ${ }^{102}$ During his employment, the plaintiff was diagnosed as an insulindependent diabetic. ${ }^{103}$ As a result of this diagnosis, the employer placed him on medical leave. ${ }^{104}$ After one year, the employer terminated the plaintiff as a truck driver and offered him a lesser paying position. ${ }^{105}$ The plaintiff sued the employer, asserting a claim under the ADA for discrimination and failure to accommodate his disability. ${ }^{106}$

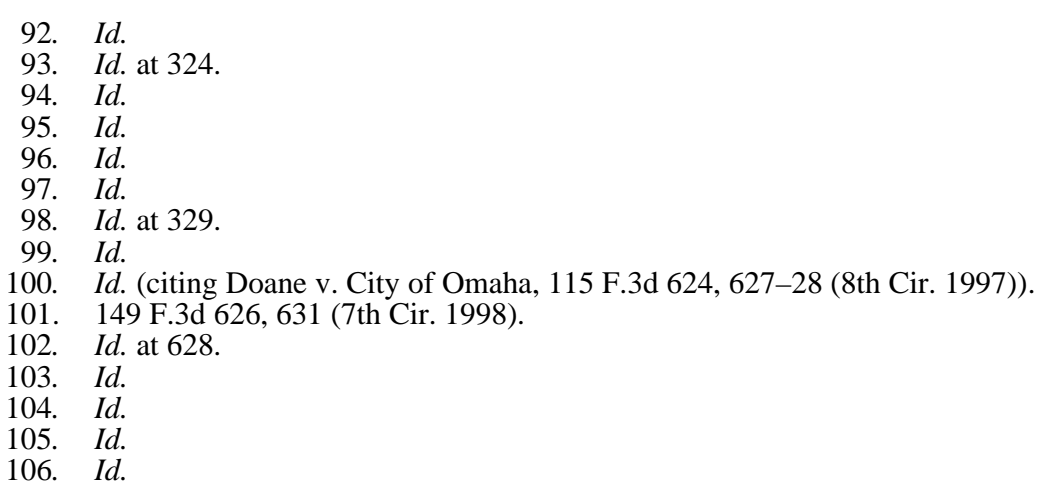


The court found that any analysis of an individual's impairment must be made without regard to mitigating measures. ${ }^{107}$ Although there was no dispute that the plaintiff was an insulin-dependent diabetic whose diabetes was under control as a result of his use of medication, the court found that in an unmedicated state the plaintiff would likely lapse into a coma and be unable to perform many major life activities. ${ }^{108}$ Indeed, the court found that the plaintiff may cease to live without proper medication. ${ }^{109}$ As a result, the plaintiff was disabled within the meaning of the ADA. ${ }^{110}$ This line of cases suggests that courts must analyze an individual's condition in its unmitigated state when determining whether a person qualifies as disabled under the ADA. Although this method may be correct in some cases, the court in Washington correctly held that taking into account mitigating measures must be done on a case-by-case analysis. The nature of the impairment and the mitigating measures employed must all be examined in order to accurately assess whether a person should be considered disabled within the meaning of the ADA.

\section{SUTTON V. UNITED AIR LINES, INC.}

In one day, the United States Supreme Court changed the ADA in a way that affected civil rights laws and related litigation for almost a decade. On June 22, 1999, the Supreme Court significantly narrowed the scope of the ADA in Sutton v. United Air Lines, Inc. ${ }^{111}$ There, the

107. Id. at 629-31.

108. Id. at 630-31.

109. Id. at 630. In reaching this conclusion, the court relied on both EEOC regulations and case law acknowledging the likely effects of untreated diabetes. Id. at 630-31; see also Turco v. Hoechst Celanese Corp., 101 F.3d 1090, 1093-94 (5th Cir. 1996); Daugherty v. City of El Paso, 56 F.3d 695, 697 n.1 (5th Cir. 1995) (discussing the EEOC Interpretive Guidance on Title I of the ADA and its classification of insulin-dependent diabetes as a disability); Bentivegna v. U.S. Dep’t of Labor, 694 F.2d 619, 621-23 (9th Cir. 1982) (addressing the Department of Labor's diabetes standard); 29 C.F.R. pt. 1630, app. $\S 1630.2(\mathrm{j})$ (1998).

110. Baert, 149 F.3d at 630.

111. 527 U.S. 471, 475 (1999), superseded by statute, ADA Amendments Act of 2008, 42 U.S.C. § 12101(a)-(b) (Supp. 2009); see also Albertson’s, Inc. v. Kirkingburg, 527 U.S. 555, 564-66 (1999) (holding that the plaintiff who learned to adjust the "manner in which he sensed depth and perceived peripheral objects" due to his monocular vision did not substantially limit his major life activities, and therefore, he was not disabled within the meaning of the ADA); Murphy v. United Parcel Serv., Inc., 527 U.S. 516, 520-21 (1999) (holding that under Sutton a plaintiff who had hypertension for which he 
Court decided that the definition of those who are disabled within the meaning of the ADA should be seriously narrowed. The Court's decision came about because lower courts had treated differently individuals who had impairments but utilized certain mitigating measures in an effort to live normal and productive lives with those impairments. After an extensive review of the ADA, the Court found that the determination of whether an individual is disabled should be made with due consideration of the effects of mitigating measures. ${ }^{112}$ This decision changed the courts' treatment of ADA plaintiffs and ultimately led Congress to amend the ADA.

In Sutton, twin sisters applied for positions as commercial airline pilots with United Air Lines. ${ }^{113}$ Each of the women suffered from severe myopia, having uncorrected vision of $20 / 200$ or worse in the right eye and 20/400 or worse in the left eye. ${ }^{114}$ The women, however, both wore corrective lenses, and these lenses enabled the plaintiffs to see with 20/20 vision or better. ${ }^{115}$ Without the use of corrective lenses, the plaintiffs could not do many daily activities, such as drive a vehicle, watch television, or shop in stores. ${ }^{116}$

United Air Lines reviewed the plaintiffs' employment applications and initially found that they met the employer's basic employment requirements. ${ }^{117}$ As a result, the employer invited the plaintiffs for interviews and related testing. ${ }^{118}$ During the interviews, however, the employer notified the plaintiffs that they failed to meet the employer's vision requirements of uncorrected vision of 20/100 or better. ${ }^{119}$ The employer, therefore, terminated each of the plaintiffs' interviews. ${ }^{120}$

The women filed suit under the ADA alleging that the employer discriminated against them on the basis of their disability. ${ }^{121}$ The district court dismissed the plaintiffs' complaint for two reasons. ${ }^{122}$ First, the district court held that the petitioners were not disabled under prong one




of the disability definition because they could fully correct their visual impairments. ${ }^{123}$ Second, the district court concluded that the plaintiffs had not sufficiently alleged that they were "regarded" by their employer as disabled under prong three of the definition. ${ }^{124}$ Similarly, the United States Court of Appeals for the Tenth Circuit agreed with the district court's analysis and affirmed the lower court's ruling, holding that "the determination of disability under the first prong should be made with regard to the beneficial impact of the twins' corrective lenses."125

The Supreme Court agreed with the court of appeals. The textualist perspective of judicial interpretation is nowhere more apparent than in the majority opinion authored by Justice O’Connor. ${ }^{126}$ In reaching its determination, the Court first reviewed the statutory and regulatory framework of the ADA. With respect to the statute, the Court noted that the ADA was meant to protect a qualified individual with a disability or an individual with a disability who, with or without reasonable accommodation, can perform the essential functions of the employment position that such individual holds or desires. ${ }^{127}$ The Court further noted that a disability is defined as "a physical or mental impairment that substantially limits one or more of the major life activities of such individual."

123. Sutton, 527 U.S. at 476.

124. Id. The district court found that the twins' allegation that their employer "regarded them as unable to satisfy the requirements of a particular job, global airline pilot," was insufficient to state a claim that they were regarded as "substantially limited in the major life activity of working." Id. at 476-77.

125. Parmet, supra note 34, at 71. The court of appeals also agreed with the district court's analysis of the third prong as it applied to the plaintiffs. Id.; see also Sutton, 527 U.S. at 476-77 (noting that the court of appeals decision diverged from a majority of appellate courts that had considered the issue of whether the impact of corrective measures should be considered for purposes of ADA protection); Bartlett v. N.Y. State Bd. of Law Exam'rs, 156 F.3d 321, 329 (2d Cir. 1998) (holding self-accommodations could not be considered when determining whether a plaintiff was disabled), vacated, 527 U.S. 1031 (1999); Baert v. Euclid Beverage, Ltd., 149 F.3d 626, 629-30 (7th Cir. 1998) (holding that disabilities should be determined without reference to mitigating measures); Matczak v. Frankford Candy \& Chocolate Co., 136 F.3d 933, 937-38 (3d Cir. 1997) (also holding that disabilities should be determined without reference to mitigating measures).

126. Justice O’Connor was joined by Chief Justice Rehnquist, and Justices Scalia, Kennedy, Souter, Thomas, and Ginsburg. Sutton, 527 U.S. at 474. Justices Stevens and Breyer both filed dissenting opinions that are clear examples of the intentionalist approach to statutory interpretation. Id. at 495 (Stevens, J., dissenting); id. at 513 (Breyer, J., dissenting).

127. Id. at 478 (majority opinion) (citing 42 U.S.C. § 12111(8) (1994)).

128. Id. (quoting 42 U.S.C. § 12102(2) (1994)). 
From a regulatory perspective, the Court acknowledged that three different government agencies had been given authority to establish regulations to implement the ADA. ${ }^{129}$ Justice O'Connor found, however, that none of the agencies had been delegated with the power or authority to define or interpret the term disability. ${ }^{130}$ Despite the apparent lack of authority to interpret the term, the EEOC attempted to provide guidance relating to the interpretation of the word disability. ${ }^{131}$ The EEOC suggested that the definition of the term disability required (1) a physical or mental impairment and (2) substantial limitation of a major life activity. ${ }^{132}$ The EEOC defined a physical impairment as including "[a]ny physiological disorder, or condition, cosmetic disfigurement, or anatomical loss affecting one or more of the following body systems: neurological, musculoskeletal, special sense organs, respiratory (including speech organs), cardiovascular, reproductive, digestive, genito-urinary, hemic and lymphatic, skin, and endocrine.”133 The EEOC also established guidelines to aid in implementing its interpretation of the term disability by courts. ${ }^{134}$ The EEOC found that "[t]he determination of whether an individual is substantially limited in a major life activity must be made on a case by case basis, without regard to mitigating measures such as medicines, or assistive or prosthetic devices." 135 The Sutton Court also discussed the EEOC's interpretive guidelines with respect to the phrases substantially limits and major life activities. Paying close attention to grammatical rules, Justice O'Connor found that the phrase "substantially limited," because it is in the present tense, "is properly read as requiring that a person be presently — not potentially or hypothetically—substantially

129. Id. at 478-79. The EEOC had authority to issue regulations related to Title I of the ADA. Id. at 478. Title I of the ADA prohibits employment discrimination against qualified individuals with disabilities by employers with fifteen or more employees. The Attorney General had authority to issue regulations with respect to Title II of the ADA. Id. at 478. Title II of the ADA provides comprehensive civil rights protections for qualified individuals with disabilities by public and private entities. The Secretary of Transportation had authority to issue regulations relating to the transportation provisions under Title II and III of the ADA. Id. at 478-79. Title III of the ADA prohibits discrimination on the basis of disability in public accommodations and requires places of public accommodations and commercial facilities to be designed, constructed, and altered in compliance with accessibility standards.

130. Id. at 479 .

131. Id.

132. Id. (citing 29 C.F.R. § 1630.2(h)-(j) (1998)).

133. Id. at 479-80 (citing 29 C.F.R. § 1630.2(h)(1)).

134. Id. at 480 .

135. Id. (emphasis added) (citing 29 C.F.R. pt. 1630, app. § 1630.2(j) (1998)). This interpretive guidance was in accord with guidance from the Department of Justice in its dealings with the Rehabilitation Act. Id. 
limited in order to demonstrate a disability."136 Moreover, major life activities is not defined. Rather, the statute contains a nonexhaustive list, which includes "functions such as caring for oneself, performing manual tasks, walking, seeing, hearing, speaking, breathing, learning, and working." 137

With respect to the interpretation of the statutory language, the majority led by Justice O'Connor declined to consider either the legislative history or the deference due to the Interpretive Guidance. ${ }^{138}$ To the majority, the text of the ADA was clear, and there was no need to consider additional clues to interpret congressional intent with respect to the ADA. ${ }^{139}$ Instead, the Court focused its decision on its interpretation of the ADA's language when read in context with three different sections of the ADA. ${ }^{140}$ First, Justice O'Connor found that the plain text of the ADA supported the majority's interpretation that the determination of whether an individual has a disability must be made without consideration of mitigating measures. ${ }^{141}$ Next, the Court found that the plain text of the ADA indicated that a disability is to be determined by considering whether, at the present time, the plaintiff is suffering from a disability such that the individual is substantially limited in a major life activity. ${ }^{142}$

136. Id. at 482. The Court continued, “A 'disability' exists only where an impairment 'substantially limits' a major life activity, not where it 'might,' 'could,' or 'would' be substantially limiting if mitigating measures were not taken.” Id.; see also 29 C.F.R. § 1630.2(j) (1998) (defining substantially limits as "[u]nable to perform a major life activity that the average person in the general population can perform," or "[s]ignificantly restricted as to the condition, manner, or duration under which an individual can perform a particular major life activity as compared to the condition, manner, or duration under which the average person in the general population can perform that same major life activity").

137. Sutton, 527 U.S. at 480 (citing 29 C.F.R. § 1630.2(i) (1998)).

138. See id. at 481-82. The Court concluded that the approach promulgated by the guidelines was an "impermissible interpretation" of the ADA. Id. at 482. The Court went on to maintain that "[l]ooking at the Act as a whole, it is apparent that if a person is taking measures ... . [to] mitigate ... a physical or mental impairment, the effects of those measures - both positive and negative-must be taken into account." Id.

139. "Although the parties dispute the persuasive force of [the EEOC's] interpretive guidelines, we have no need in this case to decide what deference is due." Id. at 480. The Court also found that "[b]ecause we decide that, by its terms, the ADA cannot be read in this manner, we have no reason to consider the ADA's legislative history." Id. at 482.

140. Id.

141. Id.

142. Id. at 482-83. 
Further, the Court noted that the determination of whether an individual has a disability must be based on an individualized inquiry into whether that individual's impairment substantially limits the individual's major life activities. ${ }^{143}$ The Court patently rejected the notion of a per se disability classification simply because an individual had been diagnosed with a specific physical or mental impairment. ${ }^{144}$ Indeed, in earlier decisions, courts had already reached a determination that a per se finding of a disability based upon a particular diagnosis was improper because an individualized inquiry is necessary to determine if a plaintiff is covered under the ADA. The Court found that the EEOC's guidance that an individual's impairment must be determined without consideration of any mitigating measures ran afoul of the required individualized inquiry under the ADA. ${ }^{145}$ Specifically, the Court noted that compliance with the EEOC guidelines would cause a court to make a determination about how certain impairments generally affect an individual, rather than how the impairment actually affected the subject individual. ${ }^{146}$ According to the Sutton Court, this type of generalized determination was contrary to the text of the ADA. ${ }^{147}$

Finally, the Court also examined the text of the ADA, which indicated that 43 million Americans suffered from a disability. ${ }^{148}$ From the majority's perspective, this number could not possibly encompass every individual who had an impairment because prior studies and reports indicated that the number of individuals who suffered from "health conditions" or impairments was approximately 160 million. ${ }^{149}$ The Court found that the reference to 43 million people must have been based on "work disability" or an individual's ability to work. ${ }^{150}$ As such, the Court found that the EEOC's guidelines could not be in accord with the ADA's plain meaning that only 43 million individuals have a disability. ${ }^{151}$

143. Id. at 483 .

144. Id. (quoting 29 C.F.R. pt. 1630, app. § 1630.2(j) (1998)) (“The determination of whether an individual has a disability is not necessarily based on the name or diagnosis of the impairment the person has, but rather on the effect of that impairment on the life of the individual.”).

145. Id.

146. Id.

147. Id.

148. Id. at 484 .

149. Id. at $486-87$.

150. Id. at 485 .

151. Id. at 487. The Court stated that:

Because it is included in the ADA's text, the finding that 43 million individuals are disabled gives content to the ADA's terms, specifically the term "disability." 
As a result of its interpretation of the plain text of the ADA, the Court found that the plaintiffs could not be disabled within the meaning of the ADA because in light of the use of mitigating measures, specifically corrective lenses, plaintiffs were not disabled. ${ }^{152}$ The Court found that it must consider the effect of the mitigating measures in order to determine whether an individual is disabled and thus afforded the protection of the ADA. ${ }^{153}$

Following the Court's decision in Sutton, courts necessarily followed suit in finding that mitigating measures must be considered when determining whether an individual is disabled within the meaning of the ADA. For example, on the same day that Sutton was decided, the Court also reached its decision in Murphy v. United Parcel Services, Inc. ${ }^{154}$ In Murphy, the plaintiff was diagnosed with severe hypertension, a condition from which he had suffered since he was ten years of age. ${ }^{155}$ The plaintiff, however, was on medication that prevented him from suffering any restrictions. ${ }^{156}$ Indeed, the plaintiff was able to do everything that other people could normally do. ${ }^{157}$ When the plaintiff was hired by United Parcel Service, he was erroneously certified to drive a commercial motor vehicle by the Department of Transportation (DOT). ${ }^{158}$ The DOT required that "the driver of a commercial motor vehicle in interstate commerce have 'no current clinical diagnosis of high blood pressure likely to interfere with his/her ability to operate a commercial vehicle safely." "159 There was no dispute that the plaintiff should not have been medically certified to operate a commercial vehicle. ${ }^{160}$ Approximately

Had Congress intended to include all persons with corrected physical limitations among those covered by the Act, it undoubtedly would have cited a much higher number of disabled persons in the findings. That it did not is evidence that the ADA's coverage is restricted to only those whose impairments are not Id. mitigated by corrective measures.

152. Id. at 488 .

153. Id. The Court, however, pointed out that a finding that the plaintiffs did not qualify as disabled under prong one of the disability definition did not preclude a finding of disability under prong three. Id. at 489.

154. 527 U.S. 516 (1999).

155. Id. at 519 .

156. Id.

157. Id.

158. Id. at 519-20.

159. Id. at 519.

160. Id. 
two months after he was hired, United Parcel Service fired plaintiff because he was unable to meet the DOT requirements related to his medical condition. ${ }^{161}$ The plaintiff filed suit asserting that he was discriminated against on the basis of his disability in violation of the ADA. ${ }^{162}$

The Court found that when the plaintiff was taking medication for hypertension, he was not substantially limited in any major life activity. ${ }^{163}$ The Court declined to consider whether the plaintiff was disabled as a result of any negative side effects from his hypertension medication. ${ }^{164}$ The Court also did not consider whether the plaintiff was disabled as a result of any persistent limitations that existed even in his medical state. ${ }^{165}$ Instead, the Court's inquiry was focused on whether mitigating measures should be considered when determining whether an individual is disabled. ${ }^{166}$ The Court noted that this question had been conclusively answered by the Court in Sutton and found that because the plaintiff was able to function without any substantial limitation in a major life activity while he was medicated, he was not disabled. ${ }^{167}$

Similarly, in Albertson's, Inc. v. Kirkingburg, the Supreme Court again refused to consider mitigating measures in determining whether an individual was disabled. ${ }^{168}$ There, the plaintiff, who was an experienced truck driver, applied for a truck driving position with the employer. ${ }^{169}$ The plaintiff performed well on the employer's road test. ${ }^{170}$ In addition to satisfactory performance on the road test, the employer required its drivers to comply with federal vision standards for commercial truck drivers. ${ }^{171}$ The DOT required that commercial truck drivers have vision of at least 20/40 in each eye. ${ }^{172}$ The plaintiff suffered from amblyopia, which caused him to have 20/200 vision in his left eye and monocular

161. Id. at 520.

162. The district court granted summary judgment holding that impairments should be evaluated in their medicated state. Id. at 520 . The court reasoned that because plaintiff functions normally when medicated, he is not disabled. Id. The court of appeals affirmed. Id.

163. Id. at 521

164. Id.

165. Id.

166. Id.

167. Id. at $521-22$.

168. 527 U.S. 555, 567 (1999).

169. Id. at 558 .

170. Id.

171. Id.

172. Id. at 558-59. 
vision. ${ }^{173}$ This condition caused the plaintiff to see using only one eye although most people see using two. ${ }^{174}$ Despite this condition, on two separate occasions, doctors erroneously certified the plaintiff as meeting the DOT's basic vision standards. ${ }^{175}$ As a result, the plaintiff was hired and worked for his employer for more than a year before becoming injured and unable to work. ${ }^{176}$ When the plaintiff sought to return to work, the employer required him to undergo further physical examination. ${ }^{177}$ During this examination, the doctor correctly assessed the plaintiff's vision and noted that he did not meet the DOT's basic vision standards. ${ }^{178}$ Although the plaintiff had the opportunity to pursue and obtain a waiver from the DOT, the employer nonetheless fired him. ${ }^{179}$ The plaintiff filed suit under the ADA alleging that the employer wrongfully discharged him as a result of his disability and in violation of the ADA. ${ }^{180}$

The Court noted that although the plaintiff suffered from monocular vision, he had learned subconsciously to adjust the "manner in which he sensed depth and perceived peripheral objects." ${ }^{81}$ The Court acknowledged that the plaintiff saw differently than most people do but that his brain had developed a mechanism for coping with the visual impairment. ${ }^{182}$ In relying on Sutton, the Court found that the plaintiff's ability to make adjustments to his vision such that he could see was, in effect, a mitigating measure. ${ }^{183}$ The Court found that the mere fact that the plaintiff saw differently than most members of society did not mean that the plaintiff was disabled. ${ }^{184}$ Instead, the proper inquiry was a consideration of whether, in light of the brain's coping mechanism, the plaintiff was substantially limited in a major life activity. ${ }^{185}$ The Court

173. Id. at 559. Amblyopia is a medical term for poor vision caused by abnormal vision development. Id. at 559 n.3.

174. Id. at 564.

175. Id. at 559 \& n. 4 .

176. Id. at $558-59$.

177. Id. at 559 .

178. Id.

179. Id. at 559-60.

180. Id. at 560. The district court granted defendant's motion for summary judgment holding that plaintiff was not a qualified individual without an accommodation. Id. at 560-61. The court of appeals reversed. Id. at 561.

181. Id. at 565.

182. Id.

183. Id. at 565-66.

184. Id. at 566.

185. Id. 
found that the plaintiff was not limited in a major life activity and that he therefore was not disabled within the meaning of the ADA. ${ }^{186}$

Sutton, Murphy, and Kirkingburg all required that a court consider mitigating measures when determining whether an individual is disabled. As discussed below, disability rights advocates and Congress took issue with this determination and once again changed the face of disability legislation with the enactment of the ADAAA.

\section{THE ADA AMENDMENTS ACT OF 2008-CONGRESSIONAL BROADENING OF ADA DISABILITY COVERAGE}

Due to Sutton and its progeny, Congress realized it needed to face the interpretation problems that existed in the years following the passage of the ADA. In fact, "[s]tudies consistently reveal[ed] that, despite the ADA, [individuals] who claim[ed] to be the victims of disability discrimination in the workplace face[d] long odds." ${ }^{\text {"187 }}$ The American Bar Association determined that during the 1990s employers prevailed in $91.6 \%$ of cases brought under the ADA. ${ }^{188}$ It can be assumed that Congress was less than thrilled with the way in which the Supreme Court handled mitigating measures in Sutton. ${ }^{189}$

One of the biggest limitations of the ADA was its vague three-pronged definition of disability. ${ }^{190}$ Additionally, the "mitigating measures" language is notably absent from the text of the ADA. ${ }^{191}$ In fact, the mitigating measures language was only added to the EEOC's issuance of

186. Id. at 567 .

187. Alex B. Long, Introducing the New and Improved Americans with Disabilities Act: Assessing the ADA Amendments Act of 2008, 103 Nw. U. L. REV. 217, 217 (2008).

188. See Dahill v. Police Dep’t of Boston, 748 N.E.2d 956, 964 n.16 (Mass. 2001) (citing Claudia MacLachlan, Employers Winning ADA Suits, NAT'L L.J., July 31, 2000, at B1).

189. The committee reports in both the House and the Senate state that the determination of whether an individual has a disability within the meaning of the ADA "should be assessed without regard to the availability of mitigating measures, such as reasonable accommodations or auxiliary aids.” H.R. REP. No. 101-485, pt. 2, at 52 (1990), reprinted in 1990 U.S.C.C.A.N. 303, 334; S. REP. No. 101-116, at 23 (1989); see also Lisa Eichhorn, Applying the ADA to Mitigating Measures Cases: A Choice of Statutory Evils, 31 ARIz. ST. L.J. 1071, 1072 (1999) (“Although the statute's convoluted language does a far from perfect job of translating Congress's intentions, the legislative history shows that the ADA was never meant to allow discrimination against people with epilepsy, diabetes, severe hearing loss, and other impairments that can be alleviated with the help of modern medicine.” (footnotes omitted)).

190. See 42 U.S.C. § 12102(2) (2006).

191. See Sarah Shaw, Why Courts Cannot Deny ADA Protection to Plaintiffs Who Do Not Use Available Mitigating Measures for Their Impairments, 90 CAL. L. REV. 1981, 2019 (2002). 
its ADA regulations and interpretive guidelines at the insistence of "disability rights groups, which were concerned that the discussion [of disability] could be misconstrued to exclude from ADA coverage individuals with disabilities who function well because of assistive devices or other mitigating measures."192 This addition exemplifies that legislative history or administrative regulations may be "slanted [and are often] drafted by ... private interest groups."193 One would hate to think that a provision, which assumedly was neither intended to be part of the language of the ADA's statute nor envisioned to be included in the EEOC's guidelines, was added in order to appease the disability rights community.

Thus, in September 2006, bipartisan legislation formulated from the recommendations by the National Council on Disability was introduced to the House of Representatives and the Senate, but the legislation subsequently failed. ${ }^{194}$ On July 26, 2007, however, an identical version of the bill entitled the ADA Restoration Act of 2007 was reintroduced. ${ }^{195}$ The predominant purpose of the ADA Restoration Act of 2007 was to "return to the broad interpretation Congress originally intended for the [ADA]." 196 When this legislation was introduced, it was described as “a modest, reasonable legislative fix . . . so that people who Congress originally intended to be protected from discrimination are covered under the ADA.”" ${ }^{197}$ This bill, however, also never came to fruition.

192. See Equal Employment Opportunities for Individuals with Disabilities, 56 Fed. Reg. 35,726, 35,727-28 (July 26, 1991).

193. Puma, supra note 56, at 144 (citing Note, Why Learned Hand Would Never Consult Legislative History Today, 105 HARV. L. REV. 1005, 1015-17 (1992)).

194. Bradley A. Areheart, When Disability Isn't “Just Right”: The Entrenchment of the Medical Model of Disability and the Goldilocks Dilemma, 83 IND. L.J. 181, 181-82 (2008). Entitled the ADA Restoration Act of 2006, the bill failed to make headway in either house. $I d$.

195. Id. at 182; see ADA Restoration Act of 2007, H.R. 3195, 110th Cong. (2007).

196. Areheart, supra note 194, at 227 (emphasis added). The ADA Restoration Act states that one of its purposes is "to reinstate original congressional intent regarding the definition of disability." H.R. 3195 § 2(b)(3). Areheart asserts that it "proceeds to demarcate a broader scope of disability than that propounded by the federal judiciary." Areheart, supra note 194, at 227 n.375.

197. Restoring Congressional Intent and Protections Under the Americans with Disabilities Act: Hearing on S. 1881 Before the S. Comm. on Health, Education, Labor, and Pensions, 110th Cong. 23-34 (2007) (statement of Camille A. Olson, partner, Seyfarth Shaw, LLP) [hereinafter Hearing on S. 1881]. 
Yet, "[o]n September 25, 2008, President George W. Bush signed into law [Senate bill] 3406," ADA, the goal of the ADAAA was equal protection in employment opportunities for individuals with disabilities. ${ }^{200}$ One of the most sweeping changes to the ADA was to the mitigating measures conundrum. Unlike the ADA, this time around, Congress expressly mandated in the ADAAA's purposes that it intended:

[T] reject the requirement enunciated by the Supreme Court in Sutton v. United Air Lines, Inc., 527 U.S. 471 (1999) and its companion cases that whether an impairment substantially limits a major life activity is to be determined with reference to the ameliorative effects of mitigating measures ... [and] to reject the Supreme Court's reasoning in Sutton v. United Air Lines, Inc., 527 U.S. 471 (1999) with regard to coverage under the third prong of the definition of disability and to reinstate the reasoning of the Supreme Court in School Board of Nassau County v. Arline, 480 U.S. 273 (1987) which set for a broad view of the third prong of the definition of handicap under the Rehabilitation Act of 1973..$^{201}$

Furthermore, Congress added an additional section to the disability definition entitled "Rules of Construction Regarding the Definition of Disability,” which maintains:

(E)(i) The determination of whether an impairment substantially limits a major life activity shall be made without regard to the ameliorative effects of mitigating measures such as-

(I) medication, medical supplies, equipment, or appliances, low-vision devices (which do not include ordinary eyeglasses or contact lenses), prosthetics including limbs and devices, hearing aids and cochlear implants or other implantable hearing devices, mobility devices, or oxygen therapy equipment and supplies ....202

The ADAAA directs that "[t]he definition of disability ... shall be construed in favor of broad coverage of individuals under this [Act], to the maximum extent permitted by the terms of this [Act]."203 In fact, the term "broaden" appears in the findings and purposes section of the

198. Sandra B. Reiss \& J. Trent Scofield, The New and Expanded Americans with Disabilities Act, 70 AlA. LAw. 39, 39 (2009). Initially, the bill had fifty-six original cosponsors; yet by September 11, 2008, it had amassed seventy-seven cosponsors. Feldblum et al., supra note 49, at 239-40.

199. ADA Amendments Act of 2008, 42 U.S.C. § 12101 (Supp. 2009); see also Long, supra note 187 , at 217 . This piece of legislation is virtually the same as was suggested by the disability rights groups during the drafting of the ADA.

200. Long, supra note 187, at 217; see also 42 U.S.C. § 12101(a).

201. ADA Amendments Act of 2008, Pub. L. No. 110-325, § 2(b)(2)-(3), 122 Stat. 3553, 3554 (2008).

202. 42 U.S.C. § 12102(4)(E)(i) (Supp. 2009); see also Reiss \& Scofield, supra note 198 , at $40-41$.

203. 42 U.S.C. § 12102(4)(A) (Supp. 2009). 
ADAAA "no less than five times."204 To illustrate, the ADAAA omitted Congress's original finding of " 43 million disabled Americans," which Toyota $^{205}$ and Sutton ${ }^{206}$ had used to narrow the ADA's coverage. ${ }^{207}$ This exemplifies Congress's utter distaste for the aforementioned Court's holdings and its ardent effort to eradicate them. ${ }^{208}$

One must wonder, however, whether focusing on broad coverage in every aspect was the most prudent, realistic decision? One can easily understand the motivations behind this congressional decision to ensure that the judicial door remains open to those who are truly disabled. There were a number of cases when truly disabled individuals were denied coverage under the ADA because the individuals mitigated their serious and at times debilitating conditions. ${ }^{209}$ On the other hand, there

204. Stephanie Wilson \& E. David Krulewicz, Disabling the ADAAA, N.J. LAW., Feb. 2009, at 31, 31; see also § 2(a)-(b), 122 Stat. at 3554.

205. Toyota Motor Mfg., Ky., Inc. v. Williams, 534 U.S. 184, 197-98 (2002), superseded by statute, ADA Amendments Act of 2008, 42 U.S.C. § 12101(a)-(b); see also Long, supra note 187, at 219, 222. The ADAAA rejected the "demanding standard" of Toyota for a looser one, recognizing that "an impairment that substantially limits one major life activity need not limit other major life activities in order to be considered a disability.” 42 U.S.C. § 12102(4)(C) (Supp. 2009). Major life activities include "caring for oneself, performing manual tasks, seeing, hearing, eating, sleeping, walking, standing, lifting, bending, speaking, breathing, learning, reading, concentrating, thinking, communicating, and working.” Id. § 12102(2)(A) (Supp. 2009). The ADAAA also stipulates that the term major life activities includes the "operation of . . . major bodily function[s], including but not limited to, functions of the immune system, normal cell growth, digestive, bowel, bladder, neurological, brain, respiratory, circulatory, endocrine, and reproductive functions." Id. $\S 12102(2)(B)$ (Supp. 2009).

206. Sutton v. United Air Lines, Inc., 527 U.S. 471, 486-87 (1999), superseded by statute, 42 U.S.C. § 12101(a)-(b).

207. ADA Amendments Act of 2008, Pub. L. No. 110-325, § 3, 122 Stat. 3553, 3554-55 (2008); see 42 U.S.C. § 12101(a).

208. In Sutton, the Court relied upon the congressional finding that there were 43 million disabled individuals to bolster its holding that the disability determination should be made with regard to mitigating measures: "Had Congress intended to include all persons with corrected physical limitations among those covered by the Act, it undoubtedly would have cited a much higher number of disabled persons in the findings.” Sutton, 527 U.S. at 487.

209. See McClure v. Gen. Motors Corp., 75 F. App’x 983 (5th Cir. 2003) (finding that muscular dystrophy was not a disability under the ADA); Orr v. Wal-Mart Stores, Inc., 297 F.3d 720, 724 (8th Cir. 2002) (holding that a diabetic was not disabled "enough" to qualify for ADA coverage); EEOC v. Sara Lee Corp., 237 F.3d 349, 350, 355 (4th Cir. 2001) (holding that epilepsy was not a disability under the ADA); Williams v. Cars Collision Ctr., LLC, No. 06 C 2105, slip op. at 9 (N.D. Ill. July 9, 2007) (holding that an amputee was not disabled under the ADA); Todd v. Acad. Corp., 57 F. Supp. 2d 448, 454 (S.D. Tex. 1999) (holding that epilepsy was not a disability under the ADA); 
were also a number of claimants who were denied coverage under the ADA because they ailed from conditions that were minor at best. ${ }^{210}$ Cases in which the plaintiffs suffer from minor and transitory conditions may now be covered under the ADAAA due to its mandate that medicated conditions constitute disabilities when they substantially limit a major life activity even if the employee does not currently suffer from any negative side effects from the impairment. In effect, the ADAAA permits and even requires a court to consider an individual's impairment in a hypothetical condition, which is not necessarily the current condition or the condition at the time the cause of action arose.

Granted, denying individuals with serious conditions, such as muscular dystrophy and other debilitating illnesses, decidedly required a change in the statutory language. Nevertheless, the ADAAA's attempt to cover truly disabled individuals that in the past may have been ignored in effect ensures that everyone suffering from impairments amounting to little more than mere annoyances may also receive coverage under prong

Phillips v. Wal-Mart Stores, Inc., 78 F. Supp. 2d 1274, 1288 (S.D. Ala. 1999) (finding that a traumatic brain injury did not qualify as a disability under the ADA).

210. See Cella v. Villanova Univ., 113 F. App’x 454, 455 (3d Cir. 2004) (holding that an employee's restriction from lifting over ten pounds because of tennis elbow did not substantially limit a major life activity); Benoit v. Technical Mfg. Corp., 331 F.3d 166, 176 (1st Cir. 2003) (holding that an employee's lower back sprain caused from weight gain “[did] not rise to the level of 'disability' or 'handicap' as defined by the statutes, because no major life activity was impaired”); Williams v. Stark County Bd. of County Comm'rs, 7 F. App’x 441, 444-47 (6th Cir. 2001) (finding that an employee suffering from migraine headaches, partly attributed to her menstrual cycle and hypertension, was not discriminated against by her employer because she failed to allege or provide evidence "that she was disqualified by her claimed disability from a broad class of jobs”); Burnett v. ESL Fed. Credit Union, 198 F. Supp. 2d 307, 316-17 (W.D.N.Y. 2002) (holding that plaintiff's reported stress did not amount to a disability); Union Carbide Corp. v. Mayfield, 66 S.W.3d 354, 366 (Tex. App. 2001) (holding that flatfootedness was not a disability when the inability to perform frequent stair climbing did not severely restrict the employee's ability to work). In the case of Sweet v. Electronic Data Systems, Inc., No. 95 Civ. 3987, 1996 WL 204471 (S.D.N.Y. Apr. 26, 1996), the court found that the employee was not disabled within the meaning of the ADA when he claimed his employer discriminated against him due to his weaker left eye-20/200 uncorrected and 20/80 corrected-which caused him to read slower and required him to rest his eyes after one hour. Id. at * 1 . The plaintiff claimed that the employer failed to accommodate him with a continued supply of thematic audio tapes. Id. at *2. However, the court held that the plaintiff's visual impairment did not constitute a disability because it did not "substantially limit his ability to participate in any major life activity." Id. at *5. The court looked to plaintiff's own testimony that “despite his eye injury, he [was] able to read, type, drive, roller-blade, play golf, and work as a sales representative without any accommodation from his employer." Id. The mere fact that he had to take a break after reading or focusing on the computer, the court felt, was "no different from the millions of Americans whose eyes, for one reason or another, tire, tear, or blur after staring at a book or computer screen for hours on end." Id. at *6. 
one of the Act's definition of disability. This is a quick fix to an even larger problem: the continued reliance on the antiquated three-pronged disability definition derived from the Rehabilitation Act. ${ }^{211}$

The ADAAA directs courts "to consider whether an impairment would substantially limit a major life activity if it were active."212 The ADAAA "allows courts to engage in this once-prohibited type of hypothetical inquiry, at least in this one instance." ${ }^{213}$ With the implementation of this statutory scheme, judges in courtrooms across this country may become modern day soothsayers utilizing their clairvoyant powers rather than their knowledge of disability laws and the actual, not hypothetical, facts of the case.

In light of these changes, the ADAAA has now included under the ever-growing umbrella of disability individuals who are otherwise substantially limited by their conditions but with the use of aids, adaptive measures, medications, and behavioral adaptations may be able to function just as any other member of society. ${ }^{214}$ The consequences of this new all-inclusive conception of disability can be rather dramatic. Surely, Congress's desire to ensure protection to the truly disabled was not meant "to extend special protections to individuals who merely need glasses to correct their vision or common medications to alleviate their high blood pressure."215 Moreover, due to the new language of the ADAAA, individuals who "in fact suffer from no limitations in their daily lives are classified as disabled and receive the full protection of the ADA [under prong one]" simply because they may be disabled in their hypothetical, unmedicated state. ${ }^{216}$ Indeed, adding the mitigating measures "safety net" to the ADAAA will undoubtedly prove to be counterproductive.

211. The ADAAA does include some changes to the way in which disability should be envisioned, such as the addition of the mitigating measures language; "attempted clarification to the Act's 'substantially limits' language; expansion of the 'major life activities' concept; and dramatic changes [to the implementation] of the 'regarded as' prong.” Long, supra note 187, at 218. Yet, the same basic, ineffective definition is still fully intact. To illustrate, it is akin to cosmetic changes to a house with a faulty foundation: eventually it will fall down.

212. Id. at 221 (emphasis omitted).

213. Id.

214. See Reiss \& Scofield, supra note 198, at 41-42.

215. Puma, supra note 56, at 145.

216. Id. 
The concern of ensuring that only the truly disabled members of society receive the full protection offered under law is not a new one. As far back as 1986, in Forrisi v. Bowen, the court warned that the high purpose of the ADA of assuring that truly disabled yet capable individuals are protected from discrimination would be debased if the statute's protections could be invoked by relatively minor and commonplace impairments. ${ }^{217}$ Congress is the voice of the people, the mouthpiece of the citizens of America, charged with prohibiting from them what must be prohibited, while at the same time, ensuring to them what must be ensured, through legislating.

In this instance, with the addition of the mitigation measures language in the ADAAA, Congress was wrong. By adding the "without regard to mitigating measures" language, Congress left the courts vulnerable to a considerable increase in ADA claimants. ${ }^{218}$ This is not to say that the ADA did not need amending. On the contrary, congressional action was necessary to put to rest the mitigating measures issue. Yet, a hard-lined approach, whether ignoring or requiring the consideration of mitigating measures, does not enable an accurate characterization of individuals who qualify for coverage under prong one. The Washington court recognized this notion and developed a scheme for interpretation of mitigating measures. The court held that "only serious impairments and ailments ... will be considered in their unmitigated state," and these impairments must "require that the individual use mitigating measures on a frequent basis, that is, he must put on his prosthesis every morning or take his medication with some continuing regularity." "219 As an illustration, the court envisioned an individual who has a "permanent correction or amelioration," such as an "artificial joint," and who, in consequence, must be evaluated in his mitigated state. ${ }^{220}$

217. 794 F.2d 931, 934 (4th Cir. 1986).

218. One example of a more prudent and effective amendment comes from author Michael J. Puma. He envisioned an amendment to the ADA reading, "The determination of whether an individual is substantially limited in a major life activity must be made on a case by case basis, with regard to mitigating measures such as medicines, medical treatments, or assistive or prosthetic devices that diminish or negate the effects of the impairment." Puma, supra note 56, at 146. Puma maintains that "[w]ith this amendment to the ADA in place, plaintiffs that the ADA previously protected, under the unmedicated approach to disability analysis, no longer would be considered disabled within the meaning of the Act.” Id.

219. Washington v. HCA Health Servs. of Tex., Inc., 152 F.3d 464, 470 (5th Cir. 1998) (emphasis added), vacated, 527 U.S. 1032 (1999). The court went on to maintain that "to ignore the mitigating measures, they must be continuous and recurring; if the mitigating measures amount to permanent corrections or ameliorations, then they may be taken into consideration.” Id. at 470-71.

220. Id. at 471 . 
To make a determination that an individual should be properly evaluated without regard to mitigating measures, the Washington court concluded that the analysis "depends on both the nature of the impairment and the mitigating measures employed by the individual.,"221 Notably, the court acquiesced that some conditions, such as diabetes, must be considered without regard to mitigating measures, whereas others, such as hip replacements, should be evaluated with regard to mitigating measures. $^{222}$ Due to the sliding scale utilized for mitigating measures determinations, the court was promoting the individualized case-by-case inquiry, while at the same time identifying those who properly should benefit from coverage under prong one. In essence, the court created a hybrid: lower courts will be mandated to evaluate "particular disease[s] and mitigating measures employed to determine whether it falls within the category of impairments that the EEOC and the legislature envisioned when the ADA was enacted."223 If the impairment is serious and the mitigation measures are "continuous and recurring," Washington directs that the measures are not to be considered for purposes of disability analysis. ${ }^{224}$

It is entirely possible that those individuals who truly suffer from economically and personally limiting impairments would not want those individuals with minor ailments calling themselves disabled, even if only for the purposes of the ADAAA. It may well be patently offensive for individuals in wheelchairs to be viewed in the same light as those who are on medication for high blood pressure. To be sure, hypertension is a serious impairment that causes hindrances in one's daily life. The hindrances caused by hypertension, however, pale in comparison to the life-altering changes caused by confinement to a wheelchair or the use of prosthetic limbs. In consequence, the Washington court's approach, which forces courts to examine the facts surrounding the plaintiff's impairment, promotes the case-by-case individualized inquiry rather than envisioning individuals in hypothetical states. ${ }^{225}$ Above all, this

221. Id.

222. Id.

223. Yvette Ostolaza \& Angela C. Wennihan, Federal Courts Divided over Whether Medication or Other Mitigating Measures Should Be Considered in Determining Whether an Employee Is "Disabled" Under the ADA, 14 LAB. LAW. 525, 529 (1999).

224. Id. at 528-29.

225. See Julia J. Hall, Sutton v. United Air Lines, Inc.: The Role of Mitigating Measures in Determining Disabilities, 51 MerCER L. REV. 799, 806-07 (1999). 
tempered approach would cause courts to determine that "[i]n some cases a person with a 'controlled' medical problem or condition will be completely functional and should be evaluated as such."226 On the other hand, courts will undoubtedly find that in other cases a person with a controlled medical condition may still be considered disabled. ${ }^{227}$

\section{CONCLUSION}

So what does the future of disability jurisprudence hold? For one, with the enactment of the ADAAA, the statute "[could] open a 'Pandora's Box' of claims by people who do not have a disability under any rational interpretation of that term." 228 Furthermore, instead of clarifying the ADA, the ADAAA actually expands it by

prohibiting consideration of mitigating measures that an individual may be using, such as medication or devices, when determining whether the individual has a disability; and ... shifting the burden of proof from employees to employers as to whether an individual is "qualified" to perform the essential functions of a job.229

By redefining the ADA's focus "away from individuals with disabilities to individuals with impairments," the ADAAA

will give virtually every employee the right to claim reasonable accommodation for some impairment, no matter how minor, unless the employer can prove that doing so would be an undue hardship. Employers will find themselves addressing potential accommodation requests from individuals with high cholesterol, back and knee strains, colds, the flu, poison ivy, sprained ankles, stomach aches, the occasional headache, a toothache, and a myriad of other minor medical conditions that go far beyond any reasonable concept of disability. ${ }^{230}$

What this means for employers is that they will be forced to make a host of workplace accommodations. From individuals "with tennis elbow who may need an arm support" to "people with ingrown fingernails who request dictation software to avoid irritating their fingers while typing," employers "may be faced with deciding whether to provide sign language interpreters for deaf employees at company meetings or special chairs or other mechanical devices to people with sore backs, tennis elbow, or sprained wrists., 231

226. Elizabeth A. Chang, Note, Who Should Have It Both Ways?: The Role of Mitigating Measures in an ADA Analysis, 64 BROOK. L. REV. 1123, 1148 (1998).

227. Id.

228. Hearing on S. 1881 , supra note 197 , at 34 .

229. Id. at 26 .

230. Id. at 27.

231. Id. at 32 
Large corporations, such as the megastores across the country employing millions of employees, may be forced to spend billions of dollars to accommodate individuals suffering from everything from flat feet to epilepsy, while the smaller businesses across the country will not be able to afford such widespread and wide-ranging accommodations. Moreover, employers may be forced to prefer

\begin{abstract}
one employee's request over another because of the perception that the request is "more justified" because of the nature of the "impairment," or because the employee makes the request first (so that the employee who sprained her ankle at [a] basketball game 2 weeks ago whose doctor has requested that she be provided a handicap parking space gets the space [over] a newly-hired employee who uses a wheelchair). ${ }^{232}$
\end{abstract}

The mitigating measures language addition to the ADAAA will also contribute to the employers' burden of accommodating employees. Not only will employers be forced to accommodate an individual "whose impairment was correctable by medication, such as hearing loss, hay fever, or asthma" but also "employees whose impairments could be readily corrected by medication but who choose not to correct them for personal reasons."233 This is not the best thing for the nation's employers or our current economic and employment situation. These are not scenarios in which employers should be placed, nor do these decisions "benefit the people whom the ADA is truly intended to protect."234

Additionally, and perhaps most importantly, the courts will undoubtedly be faced with an influx of claimants claiming ADA coverage. With the inclusion of those with minor conditions afforded coverage under prong one, the courts may be burdened by an increase in claimants alleging that their employers denied them reasonable accommodations. Above all, the addition of the "with regard to mitigating measures" language in the ADAAA is abominable to those who are truly disabled and who will now find themselves grouped in the same class as individuals who no longer suffer from their ailments.

There is no dispute that Congress needed to clarify the ADA to reflect what the citizens of this country want and demand. There is no dispute that the all-or-nothing approach that Congress and courts have taken in analyzing mitigating measures for purposes of disability classification is

232. Id.

233. Id. at 34 .

234. Id. at 32 . 
incorrect. The Washington court recognized this notion, and through its analysis, the court devised an individualized inquiry, as well as afforded protections to the truly disabled population. There is no dispute that truly disabled individuals must be protected by legislation that acknowledges their value and contribution to society. The ADA was needed to provide this necessary protection to a broader range of individuals suffering from disabilities. But the purpose of the ADA was to look at each individual and determine whether that individual was disabled yet qualified to do a specific job. The purpose was to protect that qualified disabled individual from unlawful discrimination.

In applying the ADA, a court must conduct a case-by-case analysis when making certain determinations with respect to whether an individual is disabled. Because the ADA and every court acknowledge that a caseby-case analysis must be made, it is counterintuitive to refuse to consider mitigating measures when making such determinations. A detailed analysis including consideration of mitigating measures and their effects, whether positive or negative, is appropriate and indeed necessary when conducting a complete and accurate analysis. Otherwise, and with the way the current law stands, courts will be forced to treat all insulin-dependent diabetics, for example, as disabled when hundreds of thousands of individuals live normal and productive lives with this disease. An individual who merely has been diagnosed with a disease but suffers no adverse effects from that disease should not be the intended beneficiary of the protections of the ADA under prong one. Surely, it must be that the purpose of prong one of the ADA is to protect those individuals who actually suffer from a disability and not those who, because of their use of mitigating measures, function as well as or better than most members of society.

It cannot be that the purpose of the ADA is to treat those individuals with tennis elbow or menstrual cramps the same as individuals who are wheelchair bound. ${ }^{235}$ Sadly, this can occur due to the ADAAA's blanket coverage of disability protections to the truly disabled as well as to individuals who treat their minor or transitory illnesses. The Washington court's categorization of mitigating measures by type and seriousness is the best way to analyze disabilities under prong one. Because this is not the approach proffered by the ADAAA, the dilemma of equal rights for the disabled remains unanswered.

Refusing to acknowledge such individuals under prong one, however, will not leave them without the protection of the ADA. Indeed, if an

235. See supra note 210. 
individual has a physical or mental impairment, but because of mitigating measures is able to live without experiencing the negative effects of the impairment, that individual yet has the protection of the ADA by bringing suit under prong three. ${ }^{236}$ When an individual is not currently disabled within the meaning of the Act but an employer regards the individual as disabled and discriminates against the individual because of the impairment, that employee yet has the protection of the ADA, now the ADAAA. It was unnecessary for Congress to take the all-or-nothing approach that it took in expanding the definition of a disability. As it currently stands, the ADAAA may have opened the door to more litigants, while certainly watering down the true purpose of the Act.

236. The Author recognizes that Congress has changed the definition of and criteria related to prong three. The Author also recognizes that there are still issues that exist when interpreting prong three. The issues created by these changes will be addressed in my next article about the ADAAA. 
